\title{
Рецензия на книгу: \\ Обычное международное гуманитарное право // Под ред. Жан-Мари Хенкертс, Луизы Досвальд-Бек. Кэмбридж, 2005. (Customary International Humanitarian Law / Ed. by Jean-Marie Henckaerts, Louise Doswald-Beck. Cambridge University Press, 2005.)
}

Солниев A.M.*

Фундаментальное исследование «Обьчное международное гуманитарное право» было опубликовано в 2005 г. под эгидой Международного Комитета Красного Креста (далее - МККК). Исследование состоит из двух томов: первый том называется «Нормы» (621с.), второй том ввиду громоздкости (4481с.) разделен на две книги для удобства чтения и называется «Практика». При проведении исследования были задействованы видные юристы-международники из многих стран мира. Редакторами издания выступили два сотрудника МККК: Жан-Мари Хенкертс, сотрудник правового управления МККК, и Луиза ДосвальдБек, руководитель правового управления МККК.

Предыстория создания рецензируемой книги такова. В декабре 1995 г. участники XXVI Международной конференции Красного Креста и Красного Полумесяца приняли решение поручить МККК провести комплексное исследование обычных норм международного гуманитарного права, применимых в вооруженных конфликтах международного инемеждународного характера, чтобы способствовать их более широкому применению на практике ${ }^{1}$. На основе проведенного исследования и был создан труд «Обычное международное гуманитарное

"Солнцев Александр Михайлович - аспирант кафедры международного права юридического факультета Российского университета дружбы народов (РУДН).

${ }^{1}$ XXVI Международная конференция Красного Креста и Полумесяца, Женева, 3-7.12.1995 г. Резолюция І. Международное гуманитарное право: от права кдействию. Отчет о деятельности по выполнению решений Международной конференции по защите жертв войны // Международный журнал Красного Креста. 1996. № 8. С. 58. 
право». Следует отметить, что обычное право, применяемое к морской войне, не рассматривалось, поскольку данная область права была недавно серьезно пересмотрена в Руководстве Сан-Ремо по международному праву, применимому к вооруженным конфликтам на море 2 .

Целью данного исследования было показать, что МГП не исчерпывается лишь договорными нормами, и существует огромный пласт обязательных для исполнения международных обычаев.

Несмотря на то, что интенсивный процесс кодификации норм МГП начался с 1864 г., обычное право и в XXI веке по-прежнему играет весьма заметную роль среди источников МГП. В связи с этим профессор И.И. Лукашук отмечает, что основным источником МГП является обычай ${ }^{3}$. В случае, когда какие-либо действия не урегулированы нормами МГП, действует «Оговорка Мартенса», закрепленная впервые в Преамбуле Конвенции о законах и обычаях сухопутной войны 1899 г. (г. Гаага) и повторенная позднее в ряде других международных конвенций, согласно которой «население и воюющие остаются под охраной и действием начал межлународного права, поскольку они вытекают из установившихся между образованными народами обычаев, из законов человечности и требований общественного сознания». ${ }^{4}$ Однако определить международный обычай весьма сложно - для установления обычая используются различные вспомогателыные средства: судебные рештения, доктрины, односторонние акты и действия государств, документы международньх организаций и т.д.

В процессе исследования учеными проводилась оценка практики государств в сфере МГП. Ученые-эксперты, а также группы исследо-

\footnotetext{
${ }^{2}$ Международное право. Ведение военных действий. Сборник Гаагских конвенций и иных соглашений. МККК. Москва, 1999. С. 141-202.

${ }^{3}$ И.И. Лукашук. Международное право. Особенная часть. М.: Волтерс Клувер, 2005. C. 321.

${ }^{4}$ См.: Пустогаров В. Оговорка Мартенса - история и юридическое содержание // Право и политика, 2000. № 3. Какотметил Председатель Международного Суда ООН Судья Ши Цзююн: «Международный Суд в своем Консультативном заключении о законности угрозы применения или применении ядерного оружия от 08.07.1996 г. сослался на «оговорку Мартенса» как на один из «основополагающих принципов, определяющих структуру гуманитарного права» (\$78), и указал на «продолжительность ее существования и использования в подтверждение того, что принципы и нормы гуманитарного права применимы к ядерному оружию (\$87)» (см. Выступление Председателя Международного Суда ООН Судьи Ши Цзююна по случаю посещения Международного суда Президентом РФ В.В. Путиным. Гаага, 2 ноября 2005 г. // Московский журнал международного права, 2006. № 1. С. 6.
} 
вателей занимались изучением практики государств в 47 странах (9 в Африке, 15 в Азии, 11 в Европе, 11 в Америке и 1 в АзиатскоТихоокеанском регионе), что составляет четвертую часть государств мира. В состав российской национальной исследовательской группы вошли известные специалисты в области международного права профессора Российского университета дружбы народов И.П. Блищенко и А.Х. Абашидзе. Выбор стран осуществлялся Руководящим комитетом, в состав которого вошли 12 известных профессоров в области права, отобранных с учетом принципа географического представительства. В основу исследования также легли тексты военных уставов, правовых актов национального законодательства, прецедентов, офиццальных заявлений государств, сводки командования во время войны и т.д. Важная информация была получена при анализе документов из архива МККК. Особое внимание уделялось тем странам, куда не были направлены эксперты. При этом использовались данные о ходе почти $40 \%$ вооруженных конфликтов по всему миру. Материалы, на основе которьх проводился анализ, вошли во второй том исследования. В нем приводится краткая информация о соответствуюших нормах договорного права и принятой государствами практике, включая отчеты о ходе вооруженных конфликтов, выдержки из военных инструкций, актов национального законодательства, решений национальных судов, документов межлународных конференций, а также отчетов международных судеб̆ых органов. Для оценки результатов исследования и выработки рекомендаций по его доработке МККК образовал группу академических и правительственных экспертов, участвовать в которой был приглашен профессор Дипломатической академии МИД РФ Б.Р. Тузмухамедов.

Весной 2005 г. МККК представил фундаментальное исследование, в первом томе которого был тщательно проанализирован 161 обычай международного гуманитарного права. Обычные нормы МГП классифицированы в рецензируемом исследовании по 6 основаниям:

- «Принципы проведения различий» (24 обычных нормы);

- «Лица и объекты, находящиеся под особой защитой» (21 обычная норма);

- «Конкретные методы ведения военных действий» (24 обычных нормы);

- «Вооружения» (17 обычных норм);

- «Обращение с гражданскими лицами и лицами, прекратившими 
принимать или не принимающими участия в военных действиях» (52 обычных нормы); и

- «Имплементация» (23 обычных нормы).

В первой части книги «Принципы проведения различий» анализируются обычаи МГП, действующие в следующих случаях: различие между гражданскими лицами и комбатантами и между гражданскими и военными объектами, нападение неизбирательного характера, соблюдение принципа соразмерности при нападении, принятие мер предосторожности при нападении и принятие мер предосторожности для защиты от опасностей, возникающих в результате военных операций.

В части II приводятся обычные нормы, предоставляющие защиту определенным лицам и объектам: медицинский, духовный персонал и соответствующие объекты; персонал, участвующий в операциях по оказанию помощи, и соответствующие объекты; персонал, участвующий в миротворческих операциях, и соответствугщие объекты; журналисты; зоны, находящиеся под защитой; культурные ценности; установки и сооружения, содержацие опасные силы; природная среда.

Третья часть «Конкретные методы ведения военных действий» посвящена описанию следующих обычаев: запрещение отдавать приказ не оставлять никого в живых; уничтожение и захват имущества; использование голода среди гражданского населения и доступ к гуманитарной помощи; обман и связь с неприятелем.

В четвертой части говорится об обычаях МГП, связанных с различными видами вооружения: общие принципы применения оружия, яды и отравленное оружие, ядерное, биологическое и химическое оружие, легко разворачивающиеся и сплющивающиеся пули, взрывчатые пули; оружие, основное действие которого заключается в нанесении повреждений осколками, которые не обнаруживаются в человеческом теле с помощью рентгеновских лучей, мины-ловушки, наземные мины, зажигательное оружие и ослепляющее лазерное оружие.

Самая большая, пятая часть книги «Обращение с гражданскими лицами и лицами, прекратившими принимать или не принимающими участия в военных действиях» содержит 52 обычных нормы, распределенных редакторами книги по 8 подразделам: основные гарантии; статус комбатанта и военнопленного; раненые, больные и лица, потерпевшие кораблекрушение; погибшие; пропавшие; лица, лишенные свободы; перемещение и перемещенные лица; другие лица, которым предоставляется особая защита. 
В заключительной, шестой части первого тома исследования, посвященной проблеме имплементации, собраны 23 обычных нормы МГП. Они регулируют вопросы соблюдения норм МГП, обеспечения выполнения норм МГП, ответственности и возмещения ущерба, индивидуальной ответственности и военных преступлений.

Как отмечал профессор Г.И. Тункин, проблема обычных норм международного права является одной из самых важных и вместе с тем одной из самых сложных теоретических проблем международного права. ${ }^{5}$ Благодаря выпуску двухтомного издания «Обычное межкународное гуманитарное право» разрешились многие теоретические и практические задачи. Исследование действительно поможет преодолеть ограниченность договорных норм МГП в следующих случаях:

1. Договорные нормы применимы лишы к тем государствам, которые ратифицировали договоры, содержащие их ${ }^{6}$. Однако исследования показали, что многие нормы, содержащиеся в договорах, являготся частью обычного международного права и, следовательно, применимы ко всем государствам и всем сторонам в конфликте, они должны соблюдаться государствами вне зависимости от их участия в соответствующих договорах.

2. Большинство современных вооруженных конфликтов-немеждународные, и существующие договорные нормы недостаточно подробно регулируют их (статья 3, общая для всех Женевских конвенций, положения Дополнительного протокола II и т.д.). Исследования показали, что существует значительное количество обычных норм МГП, которые гораздо более детально определяют обязанности сторон, участвующих в немеждународньх вооруженных конфликтах. Например, в то время как договорное право не содержит норм, явным образом запрещающих нанесение ударов по гражданским объектам в случае немеждународного вооруженного конфликта, нормы обычного международного права запрецают такие действия. 159 обычных норм были признаны применимыми к случаям международного конфликта, и 149 - к случаям немежлународного конфликта. В таких конфликтах как правительственные вооруженные силы, так и повстанческие силы обязаны соблюдать эти обычные нормы и могут привлекаться к ответственности в случае их несоблюдения.

\footnotetext{
${ }^{5}$ Тункин Г.И. Теория международного права. М., 2000. С. 98.

${ }^{6}$ Например, если Женевские конвенции ратифицировали абсолютное большинство государств мира (193 государства), то Дополнительный протокол I- 165, а Дополнительный протокол II - 161 государство (данные на 26.07.2006 г.).
} 
С целью популяризации выводов исследования после выхода этой книги МККК провел в Нидерландах, США, Канаде, России, Великобритании, Индии и других странах мира конференции на тему «Обычай как источник международного гуманитарного права». В этом плане следует отметить активность регионального представительства МККК в Москве, которое завершает работу над переводом на русский язык первого тома исследования.

Как отметил судья Международного Суда Абдул Г. Корома, настоящее исследование призвано инвентаризировать существующие обычные нормы, тем самым способствуя более полному соблюдению МГП и улучшению защиты жертв войны ${ }^{7}$.

Результаты исследования будут полезны для работы международных судов и трибуналов, сотрудников правительственных и неправительственных международных организаций, государственных служащих, военных юристов, юристов-международников и для всех, кто интересуется вопросами международного гуманитарного права.

${ }^{7}$ Customary International Humanitarian Law. Vol. 1, Rules/Ed. by Jean-Marie Henckaerts, Louise Doswald-Beck. Cambridge University Press. p. xii. 